IZA DP No. 6638

The Civil Rights Act and the Earnings of Lower Income Hispanic Men in the 1960's

Harriet Orcutt Duleep

Mark Regets

June 2012 


\title{
The Civil Rights Act and the Earnings of Lower Income Hispanic Men in the 1960's
}

\author{
Harriet Orcutt Duleep \\ College of William and Mary \\ and IZA \\ Mark Regets \\ National Science Foundation \\ and IZA
}

Discussion Paper No. 6638

June 2012

IZA

P.O. Box 7240

53072 Bonn

Germany

Phone: +49-228-3894-0

Fax: +49-228-3894-180

E-mail: iza@iza.org

\begin{abstract}
Any opinions expressed here are those of the author(s) and not those of IZA. Research published in this series may include views on policy, but the institute itself takes no institutional policy positions.

The Institute for the Study of Labor (IZA) in Bonn is a local and virtual international research center and a place of communication between science, politics and business. IZA is an independent nonprofit organization supported by Deutsche Post Foundation. The center is associated with the University of Bonn and offers a stimulating research environment through its international network, workshops and conferences, data service, project support, research visits and doctoral program. IZA engages in (i) original and internationally competitive research in all fields of labor economics, (ii) development of policy concepts, and (iii) dissemination of research results and concepts to the interested public.
\end{abstract}

IZA Discussion Papers often represent preliminary work and are circulated to encourage discussion. Citation of such a paper should account for its provisional character. A revised version may be available directly from the author. 


\section{ABSTRACT}

\section{The Civil Rights Act and the Earnings of Lower Income Hispanic Men in the 1960's}

This paper uses Social Security longitudinal earnings records matched to Current Population Survey data to examine changes in the relative earnings of Hispanic men during a period of dramatic change in public and private policies toward race and ethnicity characterized by, but not limited to, the Civil Rights Act of 1964. Our principle focus is to compare and contrast how lower income Hispanic and African-American men fared during the civil rights era relative to lower-income non-Hispanic whites. Although previous studies have analyzed black economic progress using annual data before and after the Civil Rights Act, this is the first study to do so for Hispanics. We follow a longitudinal sample of individuals who were in the labor market before and after the passage of the Civil Rights Act. Following the same individuals holds constant an array of unmeasured variables such as labor force selectivity and schooling quality that may correlate with the post-1964 period; our approach addresses concerns that the results are the product of changes in these variables. Of particular note - we uncover a significant acceleration following the Civil Rights Act in the relative earnings of low-income Hispanic men.

\section{NON-TECHNICAL SUMMARY}

Public and legislative attention to civil rights in the U.S. peaked with a number of major events in the mid-1960's: most notably the Civil Rights Act of 1964, but also the 1963 March on Washington, the 1965 Voting Rights Act, the 1966 birth of the Equal Employment Opportunity Commission, and the 1966 Watts riot. While racial discrimination against African Americans was clearly the policy focus of the new laws and regulatory agencies created during this period, civil rights protections were more generally extended against discrimination based on national origin, religion, and sex. This analysis provides a first-time glimpse at the year-to-year changes in Hispanic earnings before and after the Civil Rights Act. We find consistent improvement for Hispanic Americans immediately following the 1964 Civil Rights Act. The results suggest a prominent post-Civil Rights Act labor market effect for Hispanic Americans. If these results hold up to further scrutiny, one interpretation is that the Civil Rights Act and accompanying activities benefited all minorities.

JEL Classification: J48, J71, J78, J15, J18

Keywords: anti-discrimination legislation, minority economic progress, Mexican Americans, Hispanic, low income, Civil Rights Act, longitudinal administrative records

Corresponding author:

Harriet Duleep

Thomas Jefferson Program in Public Policy

College of William and Mary

Williamsburg, VA 23187-8795

USA

E-mail: hduleep@wm.edu 


\section{The Civil Rights Act and the Earnings of Lower Income Hispanic Men in the 1960's}

\section{Introduction}

The post World War II period through the early 1970’s witnessed an impressive growth in the earnings of all workers, but most dramatically a well-documented growth in the earnings of blacks relative to whites. This growth in relative earnings coincided with comparatively rapid economic growth, absolute and relative improvements for blacks in average years of education and school quality, and the legal and social changes of the civil rights revolution.

Public and legislative attention to civil rights peaked with a number of major events in the mid-1960’s: most notably the Civil Rights Act of 1964, but also the 1963 March on Washington, the 1965 Voting Rights Act, the 1966 birth of the Equal Employment Opportunity Commission, and the 1966 Watts riot. While racial discrimination against blacks was clearly the policy focus of the new laws and regulatory agencies created during this period, civil rights protections were more generally extended against discrimination based on national origin, religion, and sex.

A substantial literature has developed to determine the impact of civil rights policies on the 1960’s improvement in black relative earnings. ${ }^{1}$ Prior studies that used longitudinal data on individuals - the focus of this study_-include analyses of Social Security’s Continuous Work History Sample by Vroman (1974) and analyses of Current Population Survey data matched to Social Security longitudinal earnings data by Duleep and Regets (1990) and Card and Krueger (1993).

In contrast to the plethora of articles chronicling and exploring the relationship between civil rights policy and black economic status, much less has been written about changes during this period in the economic status of Hispanics, who received protections against employment discrimination via the national origin clause of the Civil Rights Act. Analyses of decennial census data reveal improvement from 1960 to 1970 in the relative earnings and occupational distribution of Hispanics (Bean and Tienda,

\footnotetext{
${ }^{1}$ See Donohue and Heckman (1991) and O’Neill et al. (1986) for analytical reviews of this research.
} 
1987; Carnoy, Daley, and Ojeda, 1990; DeFreitas, 1991). ${ }^{2}$ However, as it is generally believed that minorities make relative gains when the labor market tightens, the 1960-1970 improvement in the relative earnings of Hispanic men as measured by the 1960 and 1970 decennial censuses may simply reflect the lower unemployment in 1969 compared with $1959 .{ }^{3}$

Annual data would illuminate this situation. Yet unlike blacks, the Current Population Survey (CPS) did not identify Hispanics until 1969, and Social Security's Continuous Work History Study, used by Vroman to analyze black/white earnings ratios, only identified persons as white, black, and other. Thus, scholars have been unable to examine with annual data whether there was a change in relative Hispanic economic status over and above a response to improved post-1964 employment conditions. Moreover, potential changes in labor force selectivity and quality of schooling -issues prominent in the debate on black economic progress—are relevant to the Hispanic experience but have not been addressed in analyses of over-time changes in Hispanic relative earnings. ${ }^{4}$

To address this lacuna, we use longitudinal earnings data from Social Security administrative records linked to the March 1973 CPS to examine how lower income Hispanics fared before and after the 1964 Civil Rights Act compared with lower-income non-Hispanic blacks, both relative to lower-income non-Hispanic whites. ${ }^{5}$ The linked data set referred to as the 1973 CPS-IRS-SSA Exact Match File combines longitudinal annual data on individual earnings from Social Security with economic and demographic information, such as years of schooling, residential location, and marital status, from the

\footnotetext{
${ }^{2}$ Chiswick (1987) analyzes turn-of-the century data as well as 1970 and 1980 census data on Hispanics. Reimers $(1983,1985)$ analyzes anti-Hispanic wage discrimination using the 1976 Survey of Income and Education.

${ }^{3}$ Refer to DeFreitas $(1986,1991)$ for analyses of Hispanic unemployment over the business cycle. Refer to O'Neill et al. (1986) for a careful description of trends in employment and unemployment for blacks and whites from 1940-1985.

${ }^{4}$ Reimers (1983) corrects for selectivity bias in her cross-sectional analysis of anti-Hispanic wage discrimination.

${ }^{5}$ For brevity's sake, we will sometimes refer to non-Hispanic whites as whites and non-Hispanic African Americans as blacks.
} 
CPS. In particular, the file contains the earnings histories of the sample individuals from 1952 through 1975. Since the 1973 March CPS identifies Hispanic ethnicity and race, the Exact Match File permits following the earnings of African-American as well as Hispanic-American individuals from 1952 through $1975 .^{6}$

Using the matched data set, we examine annual data on relative minority earnings before and after the Civil Rights Act. Our research strategy takes advantage of the Exact Match file’s longitudinal data on individuals by tracking the same individuals who were in the labor market both before and after the passage of the Civil Rights Act. Following the same individuals holds constant an array of unmeasured variables, but most notably sample selectivity and schooling quality. ${ }^{7}$

Although the Social Security data have many advantages, their longitudinal nature being the most important, they also present challenges. Prior to 1978, earnings data were only collected from Social Security covered employment; zero earnings were recorded for persons employed in uncovered employment. As it is difficult to distinguish the unemployed, or labor force dropouts, from persons fully employed in uncovered employment, or to distinguish the partially employed from persons working in both the covered and uncovered sectors, the pre-1978 data cannot be reliably used to examine the effects of the civil rights era on unemployment. ${ }^{8}$ Immigrants are not identified on the March 1973 CPS or the

\footnotetext{
${ }^{6}$ For information and documentation on the 1973 CPS-IRS-SSA Exact Match File, refer to Aziz, Kilss, and Scheuren (1978) and DelBene (1979). As implied by its name, this exact match file also includes Internal Revenue Service tax return information.

${ }^{7}$ Researchers have followed sample cohorts of individuals (e.g., Smith and Welch, 1986; O’Neill et al, 1986; and using CPS data, Bound and Freeman, 1989). However, cohort analyses in which the observations are based on different samples are subject to the same labor force selectivity biases stemming from over time changes in labor force participation noted by Butler and Heckman (1977). Furthermore, the number of observation years available in cohort analyses are generally insufficient for controlling for changes in unemployment conditions.

${ }^{8}$ Classes of workers lacking complete coverage in our period of study include federal civilian employees, state and local government employees, small farmers, domestic workers, and irregularly employed agricultural workers. Another approach, explored and tested in Duleep (2011), is to limit the analysis to those in covered employment as recorded in 1973.
} 
administrative records matched to the CPS. ${ }^{9}$ Finally, prior to 1978 , earnings were only recorded up to the maximum amount subject to Social Security taxes. ${ }^{10}$ In this study, we sidestep the top-coding handicap by confining our exploration to persons in the lower deciles of the income distribution. ${ }^{11}$

The focus on lower income Hispanic and black men, although necessitated by the top-coding problem, is of substantial interest since an important issue is whether both high- and low-skill minorities benefit from antidiscrimination laws. For example, Richard Epstein argues that:

The antidiscrimination law also transfers within races, and for the same reason that the minimum wage does. Changes in the legal environment are not met with simple compliance in the absence of other changes.... If black labor is perceived as having lower value than white labor (for the same human capital reasons applicable to the minimum wage) then employers will seek ways to comply with the statute and evade its sting. (Epstein, 1992, p. 262.)

Just as minimum wage laws are posited to benefit higher-wage workers to the detriment of lower-wage workers, there is some argument that lower income or lower educated Hispanics and blacks were least likely to benefit from civil rights legislation.

\section{A Period of Change}

In contrast to the slow earnings growth of low-income workers in general and minority workers in particular characterizing the mid-1970's and the 1980's, ${ }^{12}$ the decades surrounding the Civil Rights

\footnotetext{
${ }^{9}$ Two other data issues should be mentioned. In order to be in the Exact Match File sample, an individual would have had to be alive and available for interview in 1973 when the CPS was taken. Sample inclusion does not necessitate, however, being in the 1973 workforce. Secondly, region of residence is that reported in 1973 and may not accurately reflect an individual's earlier geographic location(s). This contributes measurement error to our analyses that utilize the 1973-reported region of residence to link year- and region-specific employment conditions to individual earnings histories.

${ }^{10}$ For a discussion of the effect of censoring on estimated coefficients, refer to Hausman and Wise, (1977). In Duleep and Dowhan (2002) and Duleep (2011) information on the quarter an individual reached the taxable maximum is used to impute earnings above the Social Security ceiling.

${ }^{11}$ We have also used maximum likelihood estimation of the Tobit model to compare the mean earnings of whites, Hispanics, and blacks before and after the Civil Rights Act. However, a comparison of white mean earnings estimated with the Tobit model (which assumes a normally distributed error term) using the censored data with white mean earnings based on uncensored data reveals that the tobit estimates are substantially off for years when a majority of whites are censored. Furthermore, changes in the Social Security ceiling coincided with the timing of the Civil Rights Act. This created a spurious exaggeration of the post-1964 relative effect using tobit
} 
Act were characterized by rapid income growth for minorities. Table 1 shows for men $25-55$ years old ${ }^{13}$ the average annual percentage growth rate of earnings for the years 1952 through 1975 at the first through fifth decile for non-Hispanic blacks, Hispanics, and Mexican Americans, and at the first through third decile for non-Hispanic whites. ${ }^{14}$ These growth rates were estimated by regressing the natural logarithm of earnings at the specified deciles on year.

Table 1 reveals that earnings growth was inversely related to each group's position in the earnings distribution: the lower the decile, the higher the growth. At each decile, the earnings growth of blacks and Hispanics exceeds that of whites. The earnings of the first decile, or the earnings level at which 10 percent of the corresponding population earned below, grew slightly over 4 percent per annum during this period for blacks, over 5 percent for all Hispanics, and over 7 percent for Mexican Americans, the largest single group of Hispanics. ${ }^{15}$ The corresponding growth rate for non-Hispanic whites was 3.3 percent. Similarly, earnings at the second and third decile grew faster for blacks and Hispanics than for non-Hispanic whites.

Since a given decile corresponds to a different income level for each group, it is somewhat misleading to compare growth rates across groups; some of the minority/majority differences in earnings growth may result from the lower minority earnings levels. Clearly, however, intergroup differences in income levels do not fully account for the higher minority growth rates. The third decile of black male earnings exceeds the growth rate for even the lowest white decile, even though it represents higher

estimates of the white means.

${ }^{12}$ There are several analyses of the post-1975 slowdown in black economic progress (i.e. Bound and Freeman, 1989; O’Neill, 1990; and Donohue and Heckman, 1991). DeFreitas (1991) documents and analyzes corresponding erosion in Hispanic economic progress.

${ }^{13}$ Note that in order to be in the sample, a person need only be alive in 1973 when the CPS was conducted: a person who is 55 (the upper end of each year's age range) in 1952 (our earliest year) would be 76 in 1973.

${ }^{14}$ Earnings above the third decile for non-Hispanic whites are truncated by the Social Security ceiling on reported earnings for some of the years in the 1952-1975 period.

${ }^{15}$ In our sample, Mexican Americans represented 60-65 percent of the total Hispanic sample in the years 1952-1975. 
monetary earnings in each of the 24 years in the sample. For Mexican Americans, the growth rate of even the fifth decile (median earnings) exceeds that of the lowest white decile.

Relative minority education grew as well during this period (Figure 1). The mean education of African-American individuals in the 1952 labor force, as recorded in our data set, was 72 percent the mean white education level; in 1975, the mean educational level of this sample’s black labor force was 87 percent of the corresponding white labor force. The mean education of Mexican-American males in the 1952 labor force was 51 percent of the mean non-Hispanic white education; twenty-three years later, it was 71 percent of the mean non-Hispanic white education.

This was also a period of important shifts in sectoral employment. There was, in general, a decline in agricultural employment. Among white males, the proportion of men, 25 to 65 years of age, employed in agriculture decreased from 13.5 percent in 1950 to 5.1 percent in 1970 (O’Neill et al, 1986, p.83). For black men, 21 percent were employed in agriculture in 1950 compared to 5.8 percent in 1970 (O’Neill et al, 1986, p. 84). The importance of agriculture and the inter-temporal shift during the 1950-1970 period were especially impressive for Hispanic men. In 1950, roughly 30 percent of Hispanic men were in the agricultural labor force; by 1970, this had dropped to less than 10 percent (Carnoy, Daley, and Ojeda, 1990, p.10).

\section{Following the Same Individuals, 1960-1969}

To measure changes in the earnings of Hispanic and black men relative to non-Hispanic white men, we took advantage of the Exact Match File’s longitudinal individual data that makes it possible to follow the same individuals over time. Following the same individuals holds constant an array of unmeasured variables that may be correlated with the post-1964 period. Unmeasured changes in sample selectivity have been a major concern in interpreting measures of post-1964 black relative progress based on individuals in the labor force. Following the same individuals eliminates this potential bias, albeit for 
a restricted sample. With respect to the analysis of Hispanic earnings, following the same individuals eliminates potential unmeasured changes in sample selectivity due to changes in the nature and rate of entering immigrants. Following the same adults over time also holds constant quality of schooling, an unmeasured factor believed to have significantly contributed to black economic progress. Thus, restricting our analysis to the same group of persons takes out sources of change other than the Civil Rights Act.

In order to follow the same individuals in the years before and after the Civil Rights Act, the sample for each year was limited to males with Social Security covered earnings, aged 25 to 55. Eliminating or reducing the requirement that there be covered earnings in each year would reintroduce the possibility that any change we observe is due to differences in the individuals in the sample over time. ${ }^{16}$

In examining the same individuals over time, it is important to identify those whose principle source of earnings is in Social Security covered employment. Unfortunately, there is no completely satisfactory way to do this. A person covered for only a few quarters may be between uncovered jobs, or moonlighting with an uncovered primary job, or unemployed. A ten-year sample that excludes anyone with significant unemployment anytime during the period would be inappropriate for a study of minority economic progress. Our solution was to limit the sample to individuals who had positive reported earnings in each of the years 1960 through 1969 and who had at least 24 quarters of Social Security reported earnings over the 10 -year period. This allows us to include individuals with quite substantial periods of unemployment— 40 percent or more of the 10-year period—while attempting to limit the analyses to persons whose primary source of earnings was covered by Social Security. In application, the 24-quarter constraint does not eliminate any Mexican American or African American not already

\footnotetext{
${ }^{16}$ Note, however, that one potential effect of the Civil Rights Act could be to reduce the probability of being employed; by only including individuals with positive Social Security earnings in all years, we exclude lower-skilled individuals who may have been negatively affected by the Civil Rights Act. To partially address
} 
eliminated by the requirement of covered earnings in each of the ten calendar years and only 0.2 percent of whites are eliminated by this restriction.

Limiting the sample to individuals with earnings in all ten years eliminates selectivity bias in the important sense that estimates of earnings growth for the remaining sample will not be biased in the ways discussed above. Nevertheless, this sample is restrictive and thus less representative of the underlying populations in several ways. Anyone with unemployment spanning a calendar year will not be in the sample. Older workers may be under represented due to early retirement and anyone older than 25 who leaves the labor force for a year to attend school will be excluded.

More seriously, movement from non-Social-Security covered employment such as agriculture to often better paying covered employment will not be captured by this analysis. Any effect of increased employment opportunities on reducing minority unemployment or assisting movement of Hispanics and blacks out of agriculture will not be captured. Moreover, this approach excludes from the analysis a comparison of cohorts entering the labor market before and after the Civil Rights Act. Theoretically, this is where one would expect the greatest change. Individuals just beginning their careers would be more likely to take advantage of new job opportunities than experienced workers whose careers were punctuated by the Civil Rights Act: human capital investments by individuals would make mid-life career changes less likely and employers responding to the Civil Rights Act would be more likely to change their hiring practices by investing in young workers.

It was necessary to restrict our sample period to ten years, 1960-1969, five years before and five years after 1964. Although it would have been highly desirable to extend this sample period to include more variation in unemployment, this would greatly reduce the resulting sample size and age distribution of the sample. By including only individuals with earnings in each of the ten years, we have already

this issue, we present a sensitivity analysis of the effects of our sample restrictions. 
excluded many very young workers, very old workers, and workers with unusually long spells out of the labor force.

Limiting the sample to individuals in the work force both before and after the Civil Rights Act drastically reduced the sample size of non-Mexican Hispanics, many of whom were undoubtedly immigrants. ${ }^{17}$ Since reasonable sample sizes were maintained for Mexican Americans and African Americans, the analyses that follow are limited to these two groups. To maintain our focus on lower income individuals, we further limited our sample to Mexican Americans and African Americans with less than 12 years of education.

Letting our dependent variable be individual earnings permits us to control at an individual level years of schooling and potential experience (measured by age - years of schooling - six). Using the individual data also allows us to control for over-time employment conditions across regions of the country. The CPS identifies nine geographic regions. We derived a time series of unemployment rates for these regions from annual state unemployment rates, available for years after 1957, weighted by each state's contribution to total employment in the region. ${ }^{18}$ We then linked the region-specific time series of annual unemployment rates to each individual's longitudinal record according to the CPS region of residence reported in 1973.

Our focus on individual data necessitated adopting a methodology unaffected by the earnings ceiling on historical Social Security earnings data. In order to measure minority progress relative to non-Hispanic white earnings growth, we used a logit model to estimate the probability of a minority individual earning more than the second decile of earnings for non-Hispanic whites in the sample in the

\footnotetext{
${ }^{17}$ Based on the 1976 Survey of Income and Education, DeFreitas (1991, Table 5A.2) estimates for the 1976 male labor force that $92.8 \%$ of persons of Central and South American heritage and $94.4 \%$ of persons of Cuban heritage were immigrants. In contrast, 25.5\% of Mexican-origin men were immigrants.

${ }^{18}$ Annual statistics on state unemployment rates and total employment for the years 1960 through 1969 came from the 1972 Manpower Report of the President, U.S. Department of Labor, March 1972.
} 
same year. ${ }^{19}$ Thus, we use each yearly observation for an individual as an independent observation of whether the individual earned more than the second decile of earnings for non-Hispanic whites in that year. Since individuals in this sample have ten years of earnings growth over the period, it was necessary to pick a relatively low earnings decile for whites to avoid top-coding problems.

To estimate the rate of improvement in the relative earnings of Hispanics and blacks, and to test for any post-1964 acceleration in improvement, we included a log trend term with a kink allowing a change in slope after 1964 . The main time trend takes on the values $\log (60), \log (61), \ldots \log (69)$. The second time trend is a post-1964 trend that equals zero from 1960 to 1964 and then $\log (1)$ in $1965, \log (2)$ in 1966, and so forth. It is intended to capture any acceleration in relative minority earnings growth that took place following the 1964 Civil Rights Act. Since $\log (1)$ is zero, the specification that is shown in effect provides for a one-year lag between policy and effect. An alternate specification permitted a post-1966 slope change. Whereas the Civil Rights Act was passed in 1964, a 1966 change point corresponds to the practical start of enforcement with the establishment of the Equal Employment Opportunity Commission. In addition, if rapid changes in social attitudes were a factor, it can be argued that 1963-1966 was the most intense period of change.

Any functional form that is chosen imposes an assumption about how events such as the Civil Rights Act and the beginning of EEOC enforcement affected minority/majority earnings in the subsequent years. For instance, the customary use of a linear time trend that increments by one unit per year imposes the assumption that the effect after two years is double the effect the first year and the effect after three years is triple the effect of the first year. We chose a semi-log regression model since it is consistent with measurement of a policy effect that grows over time, but which produces the greatest

\footnotetext{
${ }^{19}$ This methodology was introduced in Duleep and Regets (1990) and also used by Card and Krueger (1993).
} 
year-to-year change in its initial period. The semi-log functional form should provide a good representation of a "big bang” effect of changes in the 1964-1966 period. ${ }^{20}$

To control for labor market demand conditions, we used the reciprocal of the annual national unemployment rate. Using the reciprocal of the unemployment rate in the model introduces a nonlinear relationship between the level of unemployment and minority/majority earnings that will provide a better fit if minorities increasingly benefit from equal successive reductions in the overall unemployment rate (Vroman, 1974). This functional form is consistent with a labor market dynamic in which minority workers are the last to be hired and the first to be let go over the business cycle (Thurow, 1964).

The model that we estimated is:

$P_{i, t}=\beta_{0}+\beta_{1} \operatorname{LOG}(T)+\beta_{2} \operatorname{LOG}(T 64)+\beta_{3} 1 / U_{i, t}+\beta_{4}$ Experience $_{i, t}+\beta_{5}$ Experience Squared $_{i, t}+$ $\beta_{6}$ Education $_{i}+\beta_{7}$ Education Squared $_{i}$

where $P_{i, t}=$ the probability that individual $i$ will earn more in year $t$ than the second decile of earnings for non-Hispanic whites in year $t$.

$L O G(T)=$ the main trend term, 1960: $\log (60), 1961: \log (61), \ldots$ 1969: $\log (69)$

LOG(T64) = the post-1964 trend, 1960-1964: 0, 1965: $\log (1), \ldots$ 1969: $\log (5)$

$1 / U_{i t}=$ the reciprocal of the unemployment rate in year $t$ of individual $i$ 's reported region of residence.

Experience $_{i, t}=$ age - years of schooling - six for individual $i$ in year $t$.

Education $_{i}=$ years of schooling for individual $i$.

\footnotetext{
${ }^{20}$ We experimented with other functional forms in the logit models. The log form for both the main time trend and the post-1964 (or post-1966) time trend yields a slightly better model fit, as measured by the log-likelihood, than strictly linear trend terms. Of course, the best solution is not to impose any functional form or second time trend starting point. We do this in a free-form analysis that follows in which we estimate time-dependent effects using dummy variables for each year. Such an analysis is only possible with individual data.
} 
A separate model was also estimated substituting a post-1966 time trend for the post-1964 trend.

Table 2 shows all of the estimated coefficients from the model, alternately specified with the post-1964 and post-1966 time trend, for low educated blacks by South and non-South, and for low educated Mexican Americans.

The coefficient on the overall time trend is negative for blacks in both regions, while the coefficients for the post-1964 and post-1966 trends are positive. In the South, the secondary trend coefficients are much larger and are statistically significant. Our post-1964 results for the South suggest that between 1964 and 1970, the probability of surpassing the white 20th percentile increased by 17.3 percentage points, versus 8.9 percentage points for the non-South. The estimated effect of the post-Civil Rights Act time trend is nearly doubled in both the South and non-South samples when the model is specified to allow a change in the slope of the time trend after $1966 .^{21}$

In interpreting these results, it is well to keep in mind that this is a longitudinal sample in which each year all sample individuals are a year older. What is being measured by the time trends is not simply year-specific effects upon black/white relative earnings, but how the differential changes over 10 years of the lifetime earnings profile for a given group of blacks and whites. The experience variables measure cross-sectional rather than time-series variation in experience. The negative coefficient on the overall

\footnotetext{
${ }^{21}$ One reason for our interest in examining the effect of a post-1966 time trend in addition to a post-1964 time trend is that enforcement by the Equal Employment Opportunity Commission did not begin until 1966. As noted above, in this analysis in which we follow the same individuals, the estimated post-Civil Rights Act effect for blacks is substantially larger when the model is specified to allow a change in the slope of the time trend after 1966 instead of after 1964. In contrast, the results for blacks are similar in both specifications in an analysis—not limited to the same individuals--that examined ratios of black/white earnings at various deciles over a 1952-1974 period as well as following individuals as we do here (Duleep and Regets, 1990). One can speculate that the difference between the two analyses in the relative importance of a post-1966 time trend is due to an EEOC-enforcement effect that operated primarily on those who were already hired (the sole focus of this analysis), as opposed to those who were just entering the labor market. Because current and former employees can compare their treatment with that of other employees, EEOC enforcement is best suited to address discrimination against persons already employed or previously employed in jobs; hiring discrimination is more difficult to detect. In the 1952-1974 decile analysis, the dominant effect may be through an opening (induced by the 1964 Civil Rights Act) in the employment opportunities of blacks first entering the labor market, whereas the second analysis excludes the inflow of new entrants.
} 
time trend suggests that the black/white earnings gap increases over the life cycle; the positive coefficient on the second time trend suggests that this divergence began to reverse itself after 1964.

Mexican Americans do not exhibit the same life-cycle divergence from non-Hispanic white earnings; the coefficient on the overall time trend is statistically insignificant and close to zero. The difference in life cycle patterns between blacks and Mexican Americans may be caused by differences between the two groups in age and educational composition.

However, Mexicans show a positive and statistically significant post-1964 effect that slightly exceeds the estimated post-1964 effect for southern blacks. In contrast to the black experience, shifting the slope change in the second time trend from 1964 to 1966 only slightly affects the estimated coefficient and reduces its statistical significance. The unimportance of shifting the year of the slope change for Hispanics may be because in the early years of the EEOC, Hispanics were not a focus of enforcement efforts. Figure 2 shows for each group the expected value of the probability of exceeding the white 20th percentile of earnings. ${ }^{22}$

A potential concern with the analyses thus far is that the estimated coefficients on the second time trend may merely reflect an aberration of functional form. Although imposing a functional form for the trend term is convenient for an empirical test of post-1964 effects, it may lead to misleading results if there is not in fact a clear trend in relative minority earnings following 1964. With individual data, it is possible to explore this possibility by estimating time-dependent effects using dummy variables for each year.

The estimated coefficients from a specification substituting year-specific dummy variables for the two time trends are shown in Table 3 for blacks by South and non-South, and for Mexican Americans. The results of this "free-form" analysis are consistent with our findings reported in Table 2.

\footnotetext{
${ }^{22}$ This graph is based on the model breaking at 1964 and evaluated at each group's means each year with the exception of unemployment, which is held constant at 5\%.
} 
For southern blacks, black-white earnings diverge until 1966. It seems most likely that this is due to the life-cycle effect discussed earlier as both whites and blacks in the sample gain additional years of experience. Beginning with 1966, this trend starts to reverse itself when the coefficients for the year-specific dummy variables begin to increase. This is consistent with the hypothesis (represented by the 1966 break year in previous analyses) that actual gains for the population represented by our sample might not have occurred until after the start of active enforcement. The difference between the coefficients for 1965 and 1966 are not statistically significant, so this analysis cannot be said to have identified the start date of a civil rights effect on earnings for this group.

What is important is that this analysis does show a trend of growth in the latter half of the 1960 's. ${ }^{23}$ By 1969, the probability of surpassing the 1969 white 20th percentile is 13.9 percentage points higher than in 1965. Although a similar pattern is exhibited for blacks outside of the South, the relationship is more muted and the reversal occurs later.

For Mexican Americans, the year-specific estimates show no divergence in Mexican/non-Hispanic white earnings prior to 1964, and then a striking trend of consistent improvement immediately following $1964 .{ }^{24}$ By 1969, the probability of surpassing the 1969 white 20th percentile is 25 percentage points higher than in 1964.

Since it is difficult to separate life cycle from year-specific effects in this sample, it is difficult to compare blacks and Mexican Americans on either the magnitude or the timing of the improvement in relative earnings growth. However, despite the apparent loss in relative earnings over the life cycle for blacks, we clearly find a post mid-sixties earnings improvement for both groups.

\footnotetext{
${ }^{23}$ The consistent pattern of increases in earnings in the latter half of the 1960's also suggests that the general finding of a change in the time trend would not have been affected by choice of an alternate breakpoint such as 1967.

${ }^{24}$ The results from the dummy variable analysis concerning the relative importance of the 1964 and 1966 shift dates for blacks and Mexican Americans are consistent with the findings from the analysis shown in Table 2 which imposes the 1964 and 1966 shift dates.
} 
An important concern about this analysis is that the requirement of some positive covered earnings for 24 quarters over ten consecutive calendar years, although allowing for substantial unemployment, may eliminate many lower skilled workers from the sample. If these workers were equally or more likely to benefit from the civil rights era as other workers, then this selection bias would not affect our basic result that there was a positive effect. If, however, lower skilled minority workers were negatively affected by the Civil Rights Act and accompanying changes, then this section's results may only reflect a redistribution of economic opportunities within each group.

To test the sensitivity of our model to this constraint, we wanted to vary the number of required quarters of Social Security coverage. As noted earlier, reducing the number of required quarters while maintaining the requirement of some earnings in each of ten years would have no effect on the number of blacks and Mexicans in our sample. Eliminating or reducing the requirement that there be covered earnings in each year would reintroduce the possibility that any change in minority relative earnings is due to differences in the individuals in the sample over time. We could, however, test the sensitivity of our results to the quarters' constraint by increasing the restriction to require covered earnings in all of the 40 quarters of the ten-year period, thereby excluding from the analysis all individuals with prolonged unemployment.

A comparison of logit coefficients for post-civil-rights trend terms is shown in Table 4 for both the minimum 24-quarters sample and a minimum 40-quarters sample. In general, the results are similar between the two samples, albeit with lower levels of significance for the smaller, more constrained sample. With the exception of southern blacks in the model using a 1964 break point, there is no consequential increase in the estimated effects of the post-civil-rights trend terms with the additional quarters' restriction. This result does not support the idea that the estimated post-civil-rights effect increases as those with substantial unemployment are excluded. ${ }^{25}$ As the 40-quarters restriction also

\footnotetext{
${ }^{25}$ The effect on our results of relaxing a 40-quarter restriction to a restriction requiring only some earnings in 
excludes individuals with frequent changes between covered and uncovered occupations, the comparison shown in Table 4 does not test the sensitivity of our results to excluding those with prolonged unemployment per se. However, it seems intuitively unlikely that excluding individuals who move repeatedly in and out of covered employment would have a nearly opposite effect from excluding those with unemployment.

\section{The Bracero Program}

The clear-cut turnabout at 1964 in the relative earnings of Mexican Americans in our dummy variable analysis suggests that civil rights policy significantly affected the labor market status of Mexican Americans. Yet, 1964 heralded not only the Civil Rights Act but also the end of the bracero program. The bracero program allowed Mexican workers to enter the U.S. labor market with temporary permits. An alternative or supplementary explanation for the striking post-1964 increase in the relative earnings of low-educated Mexican Americans is that the end of the bracero program increased the demand for Mexican-American labor represented in our sample.

Since braceros were only permitted to work in the agricultural sector and only regularly employed farm workers are covered by Social Security, ${ }^{26}$ it is likely that the workers who directly competed with bracero labor for employment are not in our sample. Nevertheless, the end of the bracero program could have indirectly affected the earnings of Mexican-American labor represented in our sample by increasing the demand for Mexican-American laborers who were regularly employed in agriculture, as well as Mexican-American laborers in nonagricultural pursuits. Indeed, Briggs argues that because of the bracero program "Agricultural employment in the Southwest was virtually removed from competition with the nonagricultural sector.... Moreover, the bracero program was a significant

each of the ten years may differ from the effect of relaxing the work-each-year restriction.

${ }^{26}$ Social Security coverage was extended to regularly employed farm workers in 1950 and in 1954 (U.S. Social Security Administration, 1993, p. 22). 
factor in the rapid exodus of rural Mexican Americans between 1950 and 1970 to urban labor markets....”

(Briggs, 1984, pp. 99, 101). The converse of this argument implies that the end of the bracero program may have contributed to a post-1964 Mexican-American wage increase.

Several considerations suggest that the cessation of the bracero program did not cause the large increase in the relative earnings of Mexican Americans that we observe. The number of workers entering under the bracero program increased rapidly during the 1950's reaching a peak in 1956 when nearly half a million braceros were working in the agricultural labor market of the Southwest. Thereafter, however, the demand for bracero labor steadily fell (Figure 3). The decline in the demand for bracero labor has been attributed to cotton mechanization. ${ }^{27}$ This suggests that even without the program's end, the demand for bracero labor may have continued to drop. Indeed, the decreased demand by U.S. agricultural employers for bracero labor is thought to have made passage of legislation to end the bracero program possible (Congressional Research Service, 1980). ${ }^{28}$ The declining demand for braceros before 1964 should have attenuated demand pressures stemming from the program’s discontinuation.

In addition to the general downward trend in bracero labor, two dramatic drops in bracero labor occurred prior to the cessation of the bracero program in 1964, when the number of braceros decreased by 157,452 persons. The first occurred between 1959 and 1960, when the number of braceros decreased by 121,797 persons. The second occurred between 1961 and 1962, when the number of braceros decreased by 96,442 persons. These dramatic drops were likely reactions by agricultural employers to

\footnotetext{
${ }^{27}$ A Department of Agriculture study concluded that because of increasing mechanization of cotton and a trend to less reliance on braceros, the termination of the bracero program would not adversely affect cotton production and that agricultural workers employed in cotton would be available for use in other crops. According to this report, the number of foreign workers used in harvesting cotton in 1963 was less than 10 percent of what it had been in 1958; 72 percent of the cotton crop was machine harvested in 1963 compared to 34 percent in 1958 (U.S. Department of Agriculture, 1965).

28، The ending of the bracero program during the 1960's was the result of growing opposition to the program from labor and social welfare groups, the reduced demand for agricultural labor because of increasing mechanization of cotton, and a tighter administration of the program by the Labor Department. In other words, the bracero workers became less necessary and attractive at the same time that the political climate was shifting away from support for the program because of concern about the welfare of domestic migrant workers.”
} 
U.S. government initiatives to tighten the bracero program and expectations that the program would soon be abolished. $^{29}$ Assuming that the 1960, 1962, and 1965 dips in bracero labor affected

Mexican-American wages with a similar time lag, the dramatic post-1964 increase in Mexican-American relative earnings that we measure could only be explained by these dips in bracero labor if the lag was at least 4 years. With a shorter lag, Mexican-American wages should have started increasing before 1964 following the first large dip in bracero labor.

The bracero program and legal and illegal immigration from Mexico have been viewed as highly interrelated phenomena. In testimony concerning the bracero program, the State Department noted that Mexican applications for immigrant visas increased during periods when the number of admissions under the bracero program was decreasing (Congressional Research Service, 1980, p. 54). Controlling illegal immigration from Mexico was one of the purported purposes of the bracero program; one of the concerns in ending the program was that it would increase illegal immigration. ${ }^{30}$ The bracero program, by introducing Mexican labor to the United States and facilitating the establishment of immigrant

(Congressional Research Service, 1980, p. 46).

${ }^{29}$ In 1959, a group of consultants appointed by the Secretary of Labor issued a report recommending that the bracero program be extended on a temporary basis, "conditioned on its being substantially amended so as to prevent adverse effect [on domestic workers], ensure utilization of the domestic work force, and limit the use of Mexicans to unskilled seasonal jobs.” (Mexican Farm Labor Program, Consultants’ Report, cited in Congressional Research Service, 1980, p.51). Although the bracero program was extended in 1960 without amendment, the consultants' recommendations to the Department of Labor may have affected the program's administration and instilled employer fears of imminent changes. In 1961, the bracero program was again extended, but with legislative amendments designed to protect domestic workers. For instance, braceros were statutorily limited to temporary or seasonal agricultural work and other limitations were put on the nature of the work they could perform. This legislation was also followed by changes in the administration of the program. In particular, the Department of Labor set minimum wage rates which employers were supposed to offer temporary alien agricultural workers in order to prevent their employment from adversely affecting the wages of similarly employed U.S. workers (Congressional Research Service, 1980).

${ }^{30}$ A 1963 note to the U.S. government from the Mexican Ambassador protesting the planned cessation of the bracero program underscores the expected relationship between the bracero program and illegal immigration: "It is not to be expected that the termination of an international agreement governing and regulating the rendering of service by Mexican workers in the United States will put an end to that type of seasonal migration. The aforesaid agreement is not the cause of that migration; it is the effect or result of the migratory phenomenon. Therefore, the absence of an agreement would not end the problem but rather would give rise to a de facto situation: the illegal introduction of Mexican workers in the United States....” (Congressional Research Service, 1980, p.55). Also 
networks, has also been implicated as a cause of increased illegal immigration (Briggs, 1984, 1992).

These considerations suggest that the bracero program as a source of low-skilled Mexican labor cannot be viewed in isolation from other sources of Mexican low-skilled labor. Legal and illegal immigration from Mexico must be considered as well.

Although accurate annual records of legal immigration are available from the Immigration and Naturalization Service (INS), defining and measuring illegal immigration is complex. One source of illegal immigration is aliens who enter the United States surreptitiously and illegally, circumventing inspection at the border. To measure trends in illegal immigration of this type, we have used annual records of the number of illegal aliens apprehended by the INS. Visa abusers, who enter the United States legally and then overstay their visa, constitute another source of illegal immigration. To measure trends in potential visa abusers, we have used the number of Mexican nonimmigrants, or persons who enter the United States from Mexico for stated reasons other than immigration. Neither the data on the number of Mexican illegal aliens apprehended nor the number of Mexican nonimmigrants can be used to estimate the magnitude of illegal immigration from Mexico. Nevertheless, increases and decreases in these series likely correlate with increases and decreases in illegal immigration.

The broken line in Figure 3 combines annual time series data on the number of braceros, the number of apprehended illegal aliens from Mexico, the number of nonimmigrants from Mexico, and the number of legal immigrants from Mexico. ${ }^{31}$ This combined time series could be interpreted as a rough indicator of the direction of changes over time in the magnitude of illegal, legal, and bracero immigration entering the United States from Mexico.

see Massey (2011) on this point.

${ }^{31}$ An annual record of the number of braceros entering the United States is available in Congressional Research Service, 1980, Table 2, p. 36. For the number of apprehended illegal aliens from Mexico, we use the INS annual record of deportable aliens located (Immigration and Naturalization Service, 1977, Table 23, p. 92). The annual time series of the number of nonimmigrants from Mexico and the number of legal immigrants from Mexico were obtained from Immigration and Naturalization Service, various issues. 
As is apparent from the combined time series, large dips in bracero labor are moderated when the bracero time series is combined with our measures of other sources of Mexican labor. This is because the drops in the number of braceros entering the United States that occurred in 1960, 1962, and 1965 are associated with increases in the number of legal Mexican immigrants, apprehended illegal Mexican immigrants, and Mexican nonimmigrants. This suggests that other available sources of Mexican labor likely moderated demand pressures stemming from large dips in bracero labor. In addition to moderating changes in bracero labor, the combined time series also suggests that beginning in 1962, Mexican labor entering the United States was generally increasing. To the extent that the entrance of Mexican workers affected the post-1964 wage growth of Mexican Americans in our sample, this analysis suggests that its likely effect would have been to dampen the post-1964 wage growth of Mexican Americans.

\section{Conclusion}

This analysis confirms and strengthens previous findings of a post-Civil Rights Act improvement in the relative earnings of black men controlling for overall employment conditions and, by examining the same individuals over time, circumventing over-time changes in labor force selectivity and schooling quality.

By using CPS data matched to longitudinal Social Security earnings data, this analysis provides a first-time glimpse at the year-to-year changes in Hispanic earnings before and after the Civil Rights Act. For Mexican Americans, we find a post-1964 acceleration of earnings growth when potential problems with sample changes over time are controlled by examining the same individuals over a ten-year period. In addition, our dummy variable analysis reveals a sharp and clear-cut turnabout at 1964 in the relative 
earnings of Mexican Americans. This result at first blush would indicate a significant role for civil rights policy. $^{32}$

Although much of the policy focus of the civil rights era was directed at reducing discrimination against African Americans, the findings from our analysis hint at a prominent post-Civil Rights Act labor market effect for Hispanic Americans. If these results hold up with further analysis, one interpretation is that the Civil Rights Act and accompanying activities generally benefitted all minorities. ${ }^{33}$

\footnotetext{
${ }^{32}$ Although results on Hispanic Americans are intriguing several research steps would promote a better understanding of the historical relationship between civil rights policy and Hispanic economic status. Census analyses comparing relative Hispanic socioeconomic status before and after 1964 have controlled for nativity by including explanatory variables denoting foreign birth and year of immigration. Separate analysis of the native born would more effectively control for the impact of immigration and help illuminate the role of civil rights policies. Research on Hispanic relative earnings of the type presented in this article also needs to be supplemented by studies with an institutional focus examining the relationship between the implementation of affirmative action programs, Title VII and EEOC enforcement activities, and Hispanic employment. In his analysis of affirmative action, Leonard (1984) found a positive effect of contractor status and compliance reviews on the employment of non-black minority males.

33

In an analysis of 1960-1980 decennial census data, Duleep and Sanders (2012) also find a dramatic reduction in an unexplained gap between the earnings of U.S. born Asians and whites, much of which occurred by 1970 .
} 


\section{References}

Aziz, Faye, Kilss, Beth, and Scheuren, Fritz, 1973 Current Population Survey-Administrative Record Exact Match File Codebook, Report no. 8 of Studies from Interagency Data Linkages, U.S. Social Security Administration, Office of Research and Statistics. Washington, D.C.: Government Printing Office, 1978.

Bean, Frank D. and Marta Tienda, The Hispanic Population of the United States, New York: Russell Sage Foundation, 1987.

Bound, John and Freeman, Richard B., "Black Economic Progress: Erosion of the Post-1965 Gains in the 1980's?,” in eds. Steven Shulman and William Darity, Jr., The Question of Discrimination: Racial Inequality in the U.S. Labor Market, Middletown, Conn.: Wesleyan University Press, 1989, pp. 32-49.

Briggs, Vernon M., Jr. Immigration Policy and the American Labor Force, Baltimore: The Johns Hopkins University Press, 1984.

--, Mass Immigration and the National Interest, Armonk, New York: M. E. Sharpe, 1992.

Brown, Charles, "Black-White Earnings Ratios since the Civil Rights Act of 1964: The Importance of Labor Market Dropouts,” The Quarterly Journal of Economics, February 1984, 99(1), pp. 31-44.

Butler, Richard and Heckman, James J., "The Government’s Impact on the Labor Market Status of Black Americans: A Critical Review,” in Equal Rights and Industrial Relations, ed. Leonard J.

Hausman, et al., Madison, Wisconsin: Industrial Relations Research Association, 1977, 235-81.

Card, David and Alan Krueger, “Trends in Relative Black-White Earnings Revisited.” American Economic Review Papers and Proceedings 83, May 1993.

Carnoy, Martin, Daley, Hugh and Ojeda, Raul Hinojosa, Latinos in a Changing U.S. Economy: Comparative Perspectives on the U.S. Labor Market since 1939, Inter-University Program for Latino Research, Research Foundation of the City University of New York, 1990.

Chiswick, Barry R., “The Labor Market Status of Hispanic Men,” Journal of American Ethnic History, Fall 1987, vol. 7, no. 1, 30-58.

Congressional Research Service, “Temporary Worker Programs: Background and Issues,” U.S. Senate, Ninety-sixth Congress, Second Session, Committee on the Judiciary, Washington, D.C.: U.S. Government Printing Office, February 1980.

DeFreitas, Gregory, Inequality at Work: Hispanics in the U.S. Labor Force, New York: Oxford University Press, 1991.

--, “A Time-Series Analysis of Hispanic Unemployment,” Journal of Human Resources, vol. 21, Winter 1986, 24-43.

DelBene, Linda, 1937-1976 Social Security Longitudinal Earnings Exact Match File, Report no. 9 of Studies from Interagency Data Linkages, U.S. Social Security Administration, Office of Research and Statistics. Washington, D.C.: Government Printing Office, 1979.

Donohue, John J. and Heckman, James, "Continuous Versus Episodic Change: The Impact of Civil Rights Policy on the Economic Status of Blacks,” Journal of Economic Literature, vol. 29, no. 4, December 1991, pp. 1603-1643.

Duleep, Harriet, "Earnings Growth versus Measures of Income and Education for Predicting Mortality” Michigan Research on Retirement Consortium paper, September 2011.

Duleep, Harriet and Daniel Dowhan, "Insights from Longitudinal Data on the Earnings Growth of U.S. Foreign-born Men,” Demography, August 2002.

Duleep, Harriet Orcutt and Regets, Mark C., "Civil Rights and the Relative Earnings of Black Men: Evidence from Longitudinal Earnings Data,” paper presented at the annual meeting of the American Economic Association, 1990. 
Duleep, Harriet Orcutt and Seth Sanders, "The Economic Status of Asian Americans before and after the Civil Rights Act,” IZA Discussion Paper, 2012.

Epstein, Richard A., Forbidden Grounds: The Case Against Employment Discrimination Laws, Cambridge: Harvard University Press, 1992

Freeman, Richard B., “Changes in the Labor Market for Black Americans, 1948-1972,” Brookings Papers on Economic Activity, no. 1, 1973, pp. 67-120.

--, “Black Economic Progress after 1964: Who Has Gained and Why?,” in Studies in Labor Markets, ed. Sherwin Rosen, Chicago: University of Chicago Press, 1981, pp. 247-94.

Hausman, Jerry A. and Wise, David A., "Social Experimentation, Truncated Distributions, and Efficient Estimation,” Econometrica, Vol. 45, 319-339.

Heckman, James J., “Accounting for the Economic Progress of Black Americans,” in eds. Richard R. Cornwall and Phanindra V. Wunnava, New Approaches to Economic and Social Analyses of Discrimination, New York: Praeger, 1991.

Leonard, Jonathan S., “The Impact of Affirmative Action on Employment,” Journal of Labor Economics, 1984, vol. 2, no. 4, pp. 439-462.

Massey, Douglas, "Chain Reaction: The Causes and Consequences of America's War on Immigrants,” Julian Simon Lecture Series, paper presented at Annual Migration Meeting, IZA, May 2011.

O’Neill, June, “The Role of Human Capital in Earnings Differences Between Black and White Men,” Journal of Economic Perspectives, vol. 4, Fall 1990, pp. 25-45.

O’Neill, June, Cunningham, James, Sider, Hal, and Sparks, Andrew, The Economic Progress of Black Men, U.S. Commission on Civil Rights, Washington, D.C.: Government Printing Office, 1986.

Reimers, Cordelia, "Labor Market Discrimination against Hispanic and Black Men, "Review of Economics and Statistics, vol 65, November 1983, pp. 570-79.

--, “A Comparative Analysis of the Wages of Hispanics, Blacks, and non-Hispanic Whites,” in eds. George J. Borjas and Marta Tienda, Hispanics in the U.S. Economy, Orlando, San Diego, New York: Academic Press, 1985, pp. 27-75.

Smith, James P. and Welch, Finis R., Closing the Gap, Rand Corporation, Santa Monica, CA, 1986. and Welch 1986.

--, “Black Economic Progress After Myrdal,” Journal of Economic Literature, June 1989, pp. 519-562.

Thurow, Lester, Poverty and Discrimination, Washington, D.C.: The Brookings Institution, 1969.

U.S. Department of Agriculture, “Termination of the Bracero Program,” Agricultural Economic Report No. 77, Washington, D.C., June 1965.

U.S. Department of Labor, Manpower Report of the President: 1972, March 1972.

U.S. Immigration and Naturalization Service, Statistical Yearbook of the Immigration and Naturalization Service, Washington, D.C.: U.S. Government Printing Office, various years.

U.S. Social Security Administration, Annual Statistical Supplement, 1993, Washington D.C.: Social Security Administration, August 1993.

Vroman, Wayne, “Changes in Black Workers’ Relative Earnings: Evidence from the 1960's,” in eds., George M. von Furstenberg, Ann R. Horowitz and Bennett Harrison, Patterns of Racial Discrimination, Volume II: Employment and Income, Lexington, Mass.: Lexington Books, 1974.

--, “Black Men’s Relative Earnings: Are the Gains Illusory?,” Industrial and Labor Relations Review, vol. 44, no. 1, October 1990, pp. 83-98.

Welch, Finis, "Education and Racial Discrimination,” in ed. Orley Ashenfelter and Albert Rees, Discrimination in Labor Markets, Princeton, N.J.: Princeton University Press, 1973, pp. 43-81. 


\begin{tabular}{||c|c|c|c|c||}
\hline \multicolumn{6}{||c|}{$\begin{array}{c}\text { Table 1: Earning Growth Rates by Earnings Decile } \\
\text { (Men, Ages 25-55, Years 1952-1975) }\end{array}$} \\
\hline \hline Decile & Non-Hispanic Black & All Hispanics & Mexican American & $\begin{array}{c}\text { Non-Hispanic } \\
\text { White }\end{array}$ \\
\hline 1 & .041 & .053 & .073 & .033 \\
\hline 2 & .038 & .045 & .055 & .027 \\
\hline 3 & .034 & .038 & .046 & .024 \\
\hline 4 & .033 & .033 & .039 & - \\
\hline 5 & .031 & .031 & .037 & - \\
\hline
\end{tabular}




\begin{tabular}{|c|c|c|c|}
\hline \multicolumn{4}{|c|}{$\begin{array}{l}\text { Table 2: Logit Estimates of P(Earning > White 20th Percentile) } \\
\text { (asymptotic t-statistics in parentheses) }\end{array}$} \\
\hline & $\begin{array}{l}\text { Black, Non-South } \\
\mathrm{P}=.7124, \mathrm{n}=1700\end{array}$ & $\begin{array}{l}\text { Black, South } \\
\mathrm{P}=.2869, \mathrm{n}=1760\end{array}$ & $\begin{array}{l}\text { Mexican } \\
\mathrm{P}=.4411, \mathrm{n}=1110\end{array}$ \\
\hline Intercept & $\begin{array}{l}19.6798 \\
(1.734) \\
\end{array}$ & $\begin{array}{l}15.5891 \\
(1.420) \\
\end{array}$ & $\begin{array}{l}-6.6452 \\
(-.505) \\
\end{array}$ \\
\hline Experience & $\begin{array}{l}.1455 \\
(3.424)\end{array}$ & $\begin{array}{l}.1839 \\
(3.896)\end{array}$ & $\begin{array}{l}.0779 \\
(1.4215) \\
\end{array}$ \\
\hline Experience square & $\begin{array}{l}-.0017 \\
(-2.100)\end{array}$ & $\begin{array}{l}-.0030 \\
(-3.429) \\
\end{array}$ & $\begin{array}{l}-.0018 \\
(1.775) \\
\end{array}$ \\
\hline Education & $\begin{array}{l}.1548 \\
(1.484) \\
\end{array}$ & $\begin{array}{l}2073 \\
(2.048) \\
\end{array}$ & $\begin{array}{l}.4849 \\
(5.771)\end{array}$ \\
\hline Education square & $\begin{array}{l}.0024 \\
(.325)\end{array}$ & $\begin{array}{l}-.0006 \\
(-.084) \\
\end{array}$ & $\begin{array}{l}.0252 \\
(3.443) \\
\end{array}$ \\
\hline $\log (\mathrm{T})$ & $\begin{array}{l}-5.6492 \\
(2.028)\end{array}$ & $\begin{array}{l}-4.9284 \\
(-1.841) \\
\end{array}$ & $\begin{array}{l}1.1970 \\
(.370)\end{array}$ \\
\hline$\overline{\log (T 64)}$ & $\begin{array}{l}.0354 \\
(.193) \\
\end{array}$ & $\begin{array}{l}.4727 \\
(2.561) \\
\end{array}$ & $\begin{array}{l}.4939 \\
(2.173) \\
\end{array}$ \\
\hline $1 / \mathrm{U}$ & $\begin{array}{l}.0329 \\
(2.898) \\
\end{array}$ & $\begin{array}{l}-.0162 \\
(-1.985) \\
\end{array}$ & $\begin{array}{l}-.0528 \\
(-3.657) \\
\end{array}$ \\
\hline -2 Log Likelihood & 1972.676 & 2018.331 & 1356.693 \\
\hline Intercept & $\begin{array}{l}24.8654 \\
(2.855) \\
\end{array}$ & $\begin{array}{l}9.888 \\
(1.232) \\
\end{array}$ & $\begin{array}{l}-17.8354 \\
(1.664) \\
\end{array}$ \\
\hline Experience & $\begin{array}{l}.1504 \\
(3.531) \\
\end{array}$ & $\begin{array}{l}1868 \\
(3.966) \\
\end{array}$ & $\begin{array}{l}.0790 \\
(1.439) \\
\end{array}$ \\
\hline Experience square & $\begin{array}{l}-.0018 \\
(2.219) \\
\end{array}$ & $\begin{array}{l}-.0031 \\
(-3.501) \\
\end{array}$ & $\begin{array}{l}-.0017 \\
(1.768) \\
\end{array}$ \\
\hline Education & $\begin{array}{l}.1518 \\
(1.455) \\
\end{array}$ & $\begin{array}{l}.2058 \\
(2.032) \\
\end{array}$ & $\begin{array}{l}.4859 \\
(5.737) \\
\end{array}$ \\
\hline Education square & $\begin{array}{l}.0026 \\
(.351) \\
\end{array}$ & $\begin{array}{l}-.0005 \\
(-.072) \\
\end{array}$ & $\begin{array}{l}-.0251 \\
(3.438) \\
\end{array}$ \\
\hline $\log (\mathrm{T})$ & $\begin{array}{l}-6.9201 \\
(3.206) \\
\end{array}$ & $\begin{array}{l}-3.5532 \\
(-1.811) \\
\end{array}$ & $\begin{array}{l}3.8626 \\
(1.445) \\
\end{array}$ \\
\hline $\log (\mathrm{T} 66)$ & $\begin{array}{l}.2869 \\
(1.380) \\
\end{array}$ & $\begin{array}{l}.7230 \\
(3.604) \\
\end{array}$ & $\begin{array}{l}.4109 \\
(1.670) \\
\end{array}$ \\
\hline $1 / \mathrm{U}$ & $\begin{array}{l}.0341 \\
(3.002) \\
\end{array}$ & $\begin{array}{l}-.0141 \\
(-1.719) \\
\end{array}$ & $\begin{array}{l}-.0434 \\
(3.133) \\
\end{array}$ \\
\hline -2 Log Likelihood & 1970.798 & 2011.930 & 1358.649 \\
\hline
\end{tabular}




\begin{tabular}{|c|c|c|c|}
\hline \multicolumn{4}{|c|}{$\begin{array}{l}\text { Table 3: Logit Estimates Using Year Dummies } \\
\text { (Asymptotic t-statistics in parentheses) }\end{array}$} \\
\hline & $\begin{array}{l}\text { Black, Non-South } \\
P=.7124 n=1700\end{array}$ & $\begin{array}{l}\text { Black, South } \\
\mathrm{P}=.2869 \mathrm{n}=1760\end{array}$ & $\begin{array}{l}\text { Mexican-American } \\
\mathrm{P}=.4411, \mathrm{n}=1110\end{array}$ \\
\hline Intercept & \begin{tabular}{|l}
-3.6924 \\
$(-5.416)$
\end{tabular} & $\begin{array}{l}-4.6405 \\
(6.798)\end{array}$ & $\begin{array}{l}-1.7593 \\
(2.038)\end{array}$ \\
\hline Experience & \begin{tabular}{|l}
.1492 \\
$(3.494)$
\end{tabular} & \begin{tabular}{|l}
.1874 \\
$(3.970)$
\end{tabular} & \begin{tabular}{|l}
.0792 \\
$(1.440)$
\end{tabular} \\
\hline $\begin{array}{l}\text { Experience } \\
\text { squared }\end{array}$ & \begin{tabular}{|l}
-.0018 \\
$(-2.192)$
\end{tabular} & $\begin{array}{l}-.0031 \\
(3.509)\end{array}$ & $\begin{array}{l}-.0018 \\
(1.775)\end{array}$ \\
\hline Education & $\begin{array}{l}.1491 \\
(1.427)\end{array}$ & \begin{tabular}{|l}
.2058 \\
$(2.032)$
\end{tabular} & \begin{tabular}{|l}
.4849 \\
$(5.771)$
\end{tabular} \\
\hline Education squared & $\begin{array}{l}.0028 \\
(.371)\end{array}$ & $\begin{array}{l}-.0005 \\
(-.071)\end{array}$ & \begin{tabular}{|l}
-.0252 \\
$(3.443)$
\end{tabular} \\
\hline $1 / \mathrm{U}$ & \begin{tabular}{|l}
.0393 \\
$(3.201)$
\end{tabular} & $\begin{array}{l}-.0142 \\
(-1.695)\end{array}$ & \begin{tabular}{|l}
-.0529 \\
$(3.409)$
\end{tabular} \\
\hline 1961 & $\begin{array}{l}.0937 \\
(.383)\end{array}$ & $\begin{array}{l}-.1564 \\
(-.649)\end{array}$ & $\begin{array}{l}.0701 \\
(.241)\end{array}$ \\
\hline 1962 & $\begin{array}{l}.0079 \\
(.032)\end{array}$ & $\begin{array}{l}-.1143 \\
(-.477)\end{array}$ & $\begin{array}{l}.0420 \\
(.145)\end{array}$ \\
\hline 1963 & $\begin{array}{l}-.1399 \\
(-.573)\end{array}$ & $\begin{array}{l}-.0837 \\
(-.350)\end{array}$ & $\begin{array}{l}.0044 \\
(.015)\end{array}$ \\
\hline 1964 & $\begin{array}{l}-.2565 \\
(-1.042)\end{array}$ & $\begin{array}{l}-.3175 \\
(-1.287)\end{array}$ & $\begin{array}{l}.0078 \\
(.027)\end{array}$ \\
\hline 1965 & \begin{tabular}{|l}
-.3945 \\
$(-1.528)$
\end{tabular} & \begin{tabular}{|l}
-.4019 \\
$(-1.587)$
\end{tabular} & $\begin{array}{l}.1735 \\
(.572)\end{array}$ \\
\hline 1966 & \begin{tabular}{|l}
-.6419 \\
$(-2.316)$
\end{tabular} & \begin{tabular}{|l}
-.3945 \\
$(-1.498)$
\end{tabular} & $\begin{array}{l}.5010 \\
(1.486)\end{array}$ \\
\hline 1967 & $\begin{array}{l}-.6794 \\
(-2.521)\end{array}$ & $\begin{array}{l}-.3360 \\
(-1.270)\end{array}$ & \begin{tabular}{|l}
.5829 \\
$(1.669)$
\end{tabular} \\
\hline 1968 & \begin{tabular}{|l}
-.6332 \\
$(-2.249)$
\end{tabular} & $\begin{array}{l}.0195 \\
(.075)\end{array}$ & \begin{tabular}{|l}
.8228 \\
$(2.291)$
\end{tabular} \\
\hline 1969 & \begin{tabular}{|l}
-.5100 \\
$(-1.747)$
\end{tabular} & $\begin{array}{l}.2793 \\
(1.056)\end{array}$ & $\begin{array}{l}1.0208 \\
(2.858)\end{array}$ \\
\hline
\end{tabular}




\begin{tabular}{|c|c|c|c|c|}
\hline \multicolumn{5}{|c|}{$\begin{array}{l}\text { Table 4: Logit Estimates of P(Earning > White 20th Percentile) } \\
\text { Effect of Different Sample Selection Rules } \\
\text { Males with Less than } 12 \text { Years of Education } \\
\text { (Asymptotic t-statistics in parentheses) }\end{array}$} \\
\hline $\begin{array}{l}\text { Quarters of Social Security } \\
\text { Coverage }\end{array}$ & Model & $\begin{array}{l}\text { Black } \\
\text { Non-South }\end{array}$ & $\begin{array}{l}\text { Black } \\
\text { South }\end{array}$ & Mexican \\
\hline $\begin{array}{l}\text { Minimum Quarters of Social } \\
\text { Security Coverage }=24\end{array}$ & $\log (T 64)$ & $\begin{array}{l}.0354 \\
(.193)\end{array}$ & $\begin{array}{l}.4727 \\
(2.561)\end{array}$ & $\begin{array}{l}.4939 \\
(2.173)\end{array}$ \\
\hline $\begin{array}{l}\text { Minimum Quarters of Social } \\
\text { Security Coverage }=40\end{array}$ & Log(T64) & $\begin{array}{l}-.3271 \\
(.996)\end{array}$ & $\begin{array}{l}.7046 \\
(2.856)\end{array}$ & $\begin{array}{l}.4475 \\
(1.412)\end{array}$ \\
\hline $\begin{array}{l}\text { Minimum Quarters of Social } \\
\text { Security Coverage }=24\end{array}$ & Log(T66) & $\begin{array}{l}.2869 \\
(1.380)\end{array}$ & $\begin{array}{l}.7230 \\
(3.604)\end{array}$ & $\begin{array}{l}.4109 \\
(1.671)\end{array}$ \\
\hline $\begin{array}{l}\text { Minimum Quarters of Social } \\
\text { Security Coverage }=40\end{array}$ & Log(T66) & $\begin{array}{l}.2312 \\
(.643)\end{array}$ & $\begin{array}{l}.7338 \\
(2.694)\end{array}$ & $\begin{array}{l}.1558 \\
(.4516)\end{array}$ \\
\hline
\end{tabular}




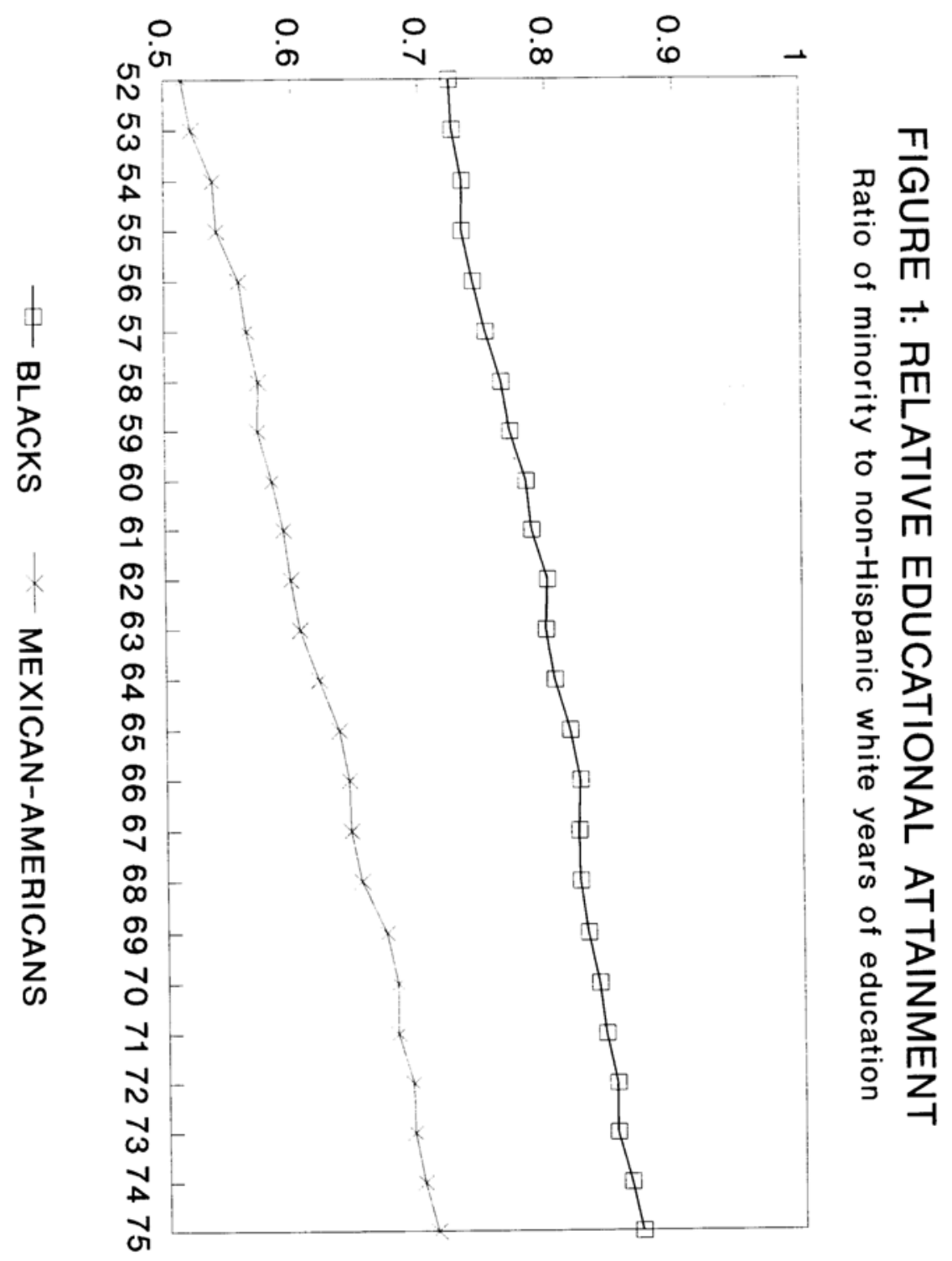




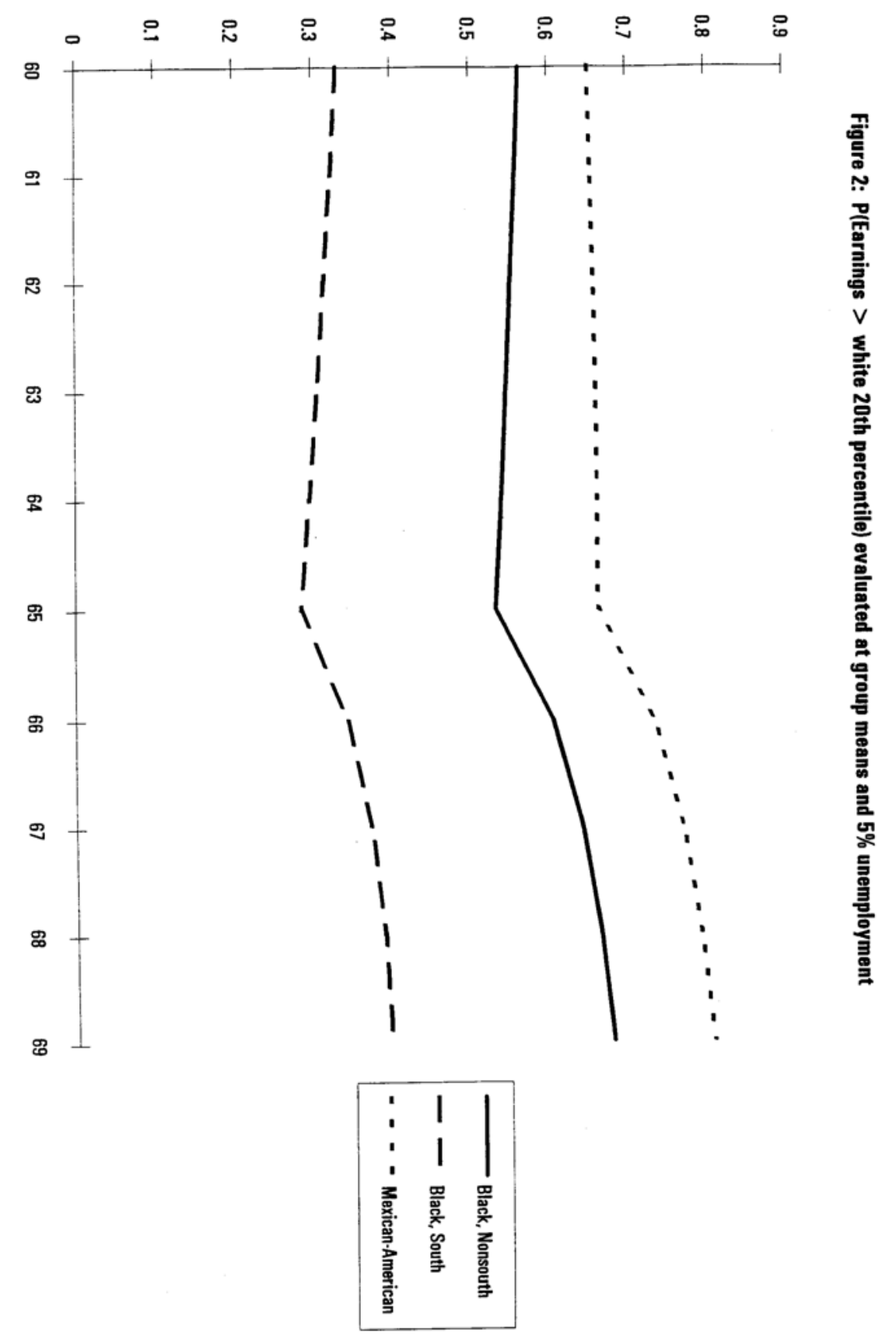




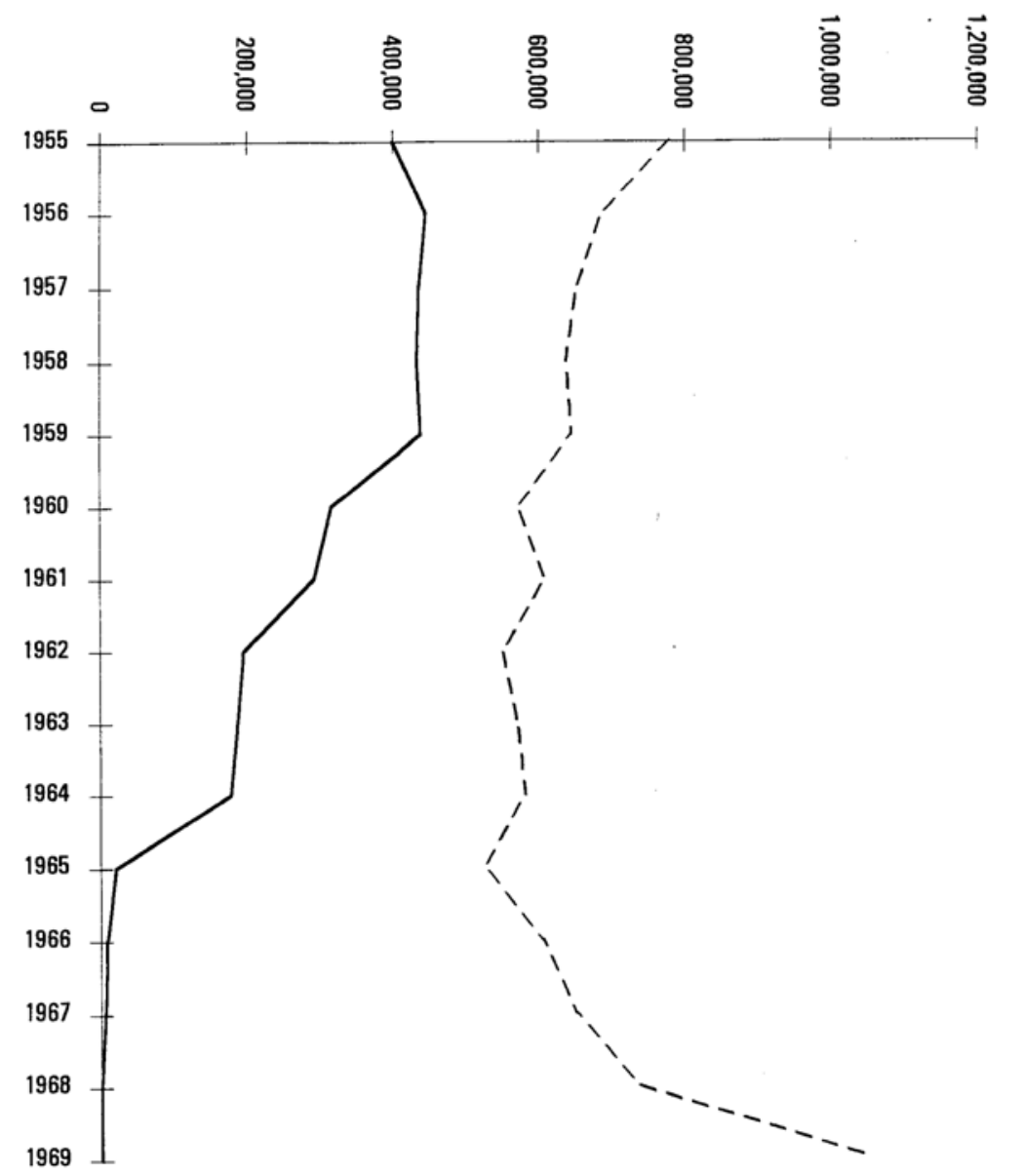

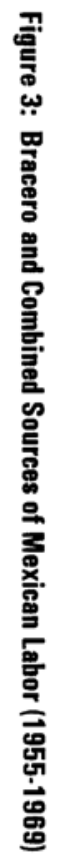

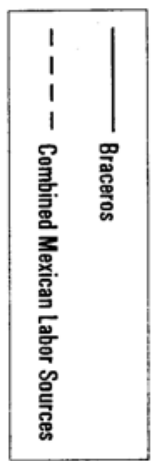

